\title{
Mitochondrial Metal Ion Transport in Cell Metabolism and Disease
}

\author{
Xuan Wang ${ }^{1,+}$, Peng An ${ }^{1,+}$, Zhenglong Gu ${ }^{2}$, Yongting Luo $1, * \mathbb{D}$ and Junjie Luo $1, * \mathbb{D}$ \\ 1 Beijing Advanced Innovation Center for Food Nutrition and Human Health, Key Laboratory of Precision \\ Nutrition and Food Quality, Department of Nutrition and Health, China Agricultural University, \\ Beijing 100193, China; xuanwxuan@outlook.com (X.W.); an-peng@cau.edu.cn (P.A.) \\ 2 Division of Nutritional Sciences, Cornell University, Ithaca, NY 14853, USA; zg27@Cornell.edu \\ * Correspondence: luo_yongting@163.com (Y.L.); luojj@cau.edu.cn (J.L.) \\ + These authors contributed equally to this work as co-first author.
}

Citation: Wang, X.; An, P.; Gu, Z.; Luo, Y.; Luo, J. Mitochondrial Metal Ion Transport in Cell Metabolism and Disease. Int. J. Mol. Sci. 2021, 22, 7525 . https://doi.org/10.3390/ ijms22147525

Academic Editors:

Salvatore Passarella and

Vladimir Titorenko

Received: 31 May 2021

Accepted: 13 July 2021

Published: 14 July 2021

Publisher's Note: MDPI stays neutral with regard to jurisdictional claims in published maps and institutional affiliations.

Copyright: () 2021 by the authors. Licensee MDPI, Basel, Switzerland. This article is an open access article distributed under the terms and conditions of the Creative Commons Attribution (CC BY) license (https:// creativecommons.org/licenses/by/ $4.0 /)$.

\begin{abstract}
Mitochondria are vital to life and provide biological energy for other organelles and cell physiological processes. On the mitochondrial double layer membrane, there are a variety of channels and transporters to transport different metal ions, such as $\mathrm{Ca}^{2+}, \mathrm{K}^{+}, \mathrm{Na}^{+}, \mathrm{Mg}^{2+}, \mathrm{Zn}^{2+}$ and $\mathrm{Fe}^{2+} / \mathrm{Fe}^{3+}$. Emerging evidence in recent years has shown that the metal ion transport is essential for mitochondrial function and cellular metabolism, including oxidative phosphorylation (OXPHOS), ATP production, mitochondrial integrity, mitochondrial volume, enzyme activity, signal transduction, proliferation and apoptosis. The homeostasis of mitochondrial metal ions plays an important role in maintaining mitochondria and cell functions and regulating multiple diseases. In particular, channels and transporters for transporting mitochondrial metal ions are very critical, which can be used as potential targets to treat neurodegeneration, cardiovascular diseases, cancer, diabetes and other metabolic diseases. This review summarizes the current research on several types of mitochondrial metal ion channels/transporters and their functions in cell metabolism and diseases, providing strong evidence and therapeutic strategies for further insights into related diseases.
\end{abstract}

Keywords: mitochondrial metal ion transport; mitochondrial metal ion homeostasis; mitochondrial function; cell metabolism; disease

\section{Introduction}

Mitochondria are cytoplasmic organelles crucial to life. Since the major function of mitochondria is to produce a large amount of energy ATP, they are called the powerhouse of the cell. However, the functions of mitochondria are multifaceted, far beyond bioenergetics, such as cell metabolism, apoptosis, fatty acid $\beta$-oxidation, reactive oxygen species (ROS) signaling, steroid synthesis, and metal ion homeostasis [1-5]. Mitochondria have a double membrane structure, namely mitochondrial inner membrane (MIM) and mitochondrial outer membrane (MOM), both of which contain selective and nonselective ion channels and transporters [6,7]. The MOM with a simple structure is a permeable membrane for small molecules and ions, while the MIM is highly impermeable and its passive transport mode is usually driven by electrochemistry [8,9]. The recently discovered mitochondrial metal ion channels/transporters are mainly located on these mitochondrial membranes, especially the MIM. While some metal ion channels/transporters participate in normal physiological activities, others only play their roles in pathological states, both of which are essential for cell survival and metabolism. Moreover, mitochondrial metal ion channels/transporters are considered to be important communication media between mitochondria and cytoplasm. Unbalanced communication causes disorders of cell metabolism and energy supply, leading to multiple pathologies $[10,11]$.

Impaired metal ion homeostasis at the cellular level is linked to mitochondrial dysfunction $[12,13]$. The dynamic balance of metal ions inside and outside the mitochondria plays 
significant roles in numerous cellular physiological processes, including activating ATPase, maintaining ATP production, keeping the homeostasis of mitochondrial volume, regulating the concentration of ROS, controlling signal transduction, and holding the balance of other ion concentrations. Furthermore, it has been reported that the metal ion dyshomeostasis in mitochondria is related to pathological features in neurodegenerative diseases, such as Alzheimer's disease and Parkinson's disease [12,14,15]. In addition, diseases related to mitochondrial metal ion dyshomeostasis also include cancer, type 2 diabetes (T2D), heart failure, ischemia and reperfusion injury [16-20]. It is particularly important to note that targeting certain mitochondrial metal ion channels/transporters can treat diseases, such as hypoxic pulmonary artery hypertension, cancer and neurodegenerative disorders [21-23].

As far as we know, although the current research on mitochondrial metal ion transport is still limited, it has been found that there are several specific channels/transporters on the inner or outer membrane of mitochondria, which are responsible for transporting different metal cations, such as $\mathrm{Ca}^{2+}, \mathrm{K}^{+}, \mathrm{Na}^{+}, \mathrm{Mg}^{2+}, \mathrm{Zn}^{2+}$ and $\mathrm{Fe}^{2+} / \mathrm{Fe}^{3+}$ (Table 1). Mitochondrial channels/transporters and transports of metal cations are the key to modulating metal ion homeostasis directly or indirectly, which is essential for mitochondrial function, cellular metabolism, health and disease (Figure 1). Herein, our review summarizes the current relevant studies and focuses primarily on several types of mitochondrial metal ion transport and their roles in cell metabolism and diseases. Not only can it provide a reference for in-depth research on the transport of mitochondrial metal ions, but is also expected to develop more disease treatment strategies.

\section{Mitochondrial Channels / Transporters}

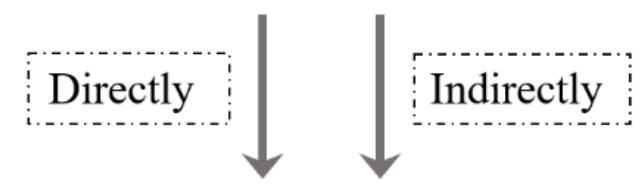

\section{Metal Ion Homeostasis}

\section{Mitochondrial Function}

e.g. OXPHOS, mitophagy, ROS
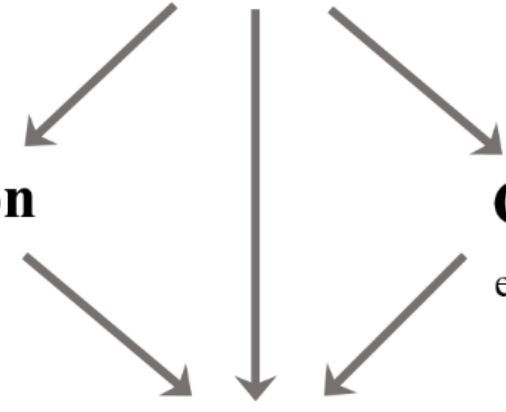

\section{Health and Disease}

e.g. neurodegeneration, cardiovascular diseases

Figure 1. Mitochondrial channels/transporters transport various kinds of metal ions, which directly or indirectly regulates the homeostasis of metal ions. The metal ion homeostasis is essential for mitochondrial function, cellular metabolism, health and disease. 
Table 1. Different mitochondrial channels/transporters transport various metal ions, which are closely related to many types of diseases. Most of the discovered mitochondrial metal ion channels/transporters are located on the MIM, but there are a few exceptions, such as VDAC and DMT1 (on the MOM).

\begin{tabular}{|c|c|c|c|c|}
\hline \multirow{2}{*}{ Metal Ions } & \multicolumn{2}{|c|}{ Mitochondrial Channels/Transporters } & \multirow{2}{*}{ Related Diseases } & \multirow{2}{*}{ References } \\
\hline & Importer/Influx & Exporter/Efflux & & \\
\hline $\mathrm{Ca}^{2+}$ & VDAC, MCU, mRYR & Letm1, NCLX, mPTP & $\begin{array}{l}\text { Insulin resistance, T2D, } \\
\text { Diabetes-related cardiac } \\
\text { disease, Heart failure, } \\
\text { Ischemia, Reperfusion } \\
\text { injury, Brain aging, } \\
\text { Neurodegenerative } \\
\text { diseases, Cancer }\end{array}$ & {$[17,20,24-36]$} \\
\hline $\mathrm{K}^{+}$ & $\begin{array}{l}\text { mitoKATP, } \mathrm{KCa}, \mathrm{Kv}, \\
\text { mitoTASK-3 }\end{array}$ & KHE & $\begin{array}{c}\text { Epilepsy, Diabetic } \\
\text { cardiomyopathy, Ischemia, } \\
\text { Reperfusion injury, } \\
\text { Pulmonary artery } \\
\text { hypertension, } \\
\text { Neurodegeneration, } \\
\text { Cancer, Schizophrenia, } \\
\text { Sudden cardiac death }\end{array}$ & [37-53] \\
\hline $\mathrm{Na}^{+}$ & NCLX & NHE & $\begin{array}{c}\text { Heart failure, Sudden } \\
\text { death, Neurodegenerative } \\
\text { diseases }\end{array}$ & {$[18,35,54-57]$} \\
\hline $\mathrm{Mg}^{2+}$ & MRS2 & SLC41A3, Mme1 & $\begin{array}{l}\text { Cancer, Demyelination, } \\
\text { Neurodegeneration }\end{array}$ & [58-65] \\
\hline $\mathrm{Zn}^{2+}$ & $\mathrm{MCU}, \mathrm{ZnT} 4$ & ZIP8, mitoKATP & Neurodegeneration & {$[66-71]$} \\
\hline $\mathrm{Fe}^{2+} / \mathrm{Fe}^{3+}$ & MFRN, Tf/TfR2, DMT1 & - & $\begin{array}{c}\text { Anemia, } \\
\text { Neurodegenerative } \\
\text { diseases }\end{array}$ & [72-81] \\
\hline
\end{tabular}

\section{Mitochondrial $\mathrm{Ca}^{2+}$}

Mitochondria produce ATP through OXPHOS to provide energy for various physiological activities in cells, and the $\mathrm{Ca}^{2+}$ concentration in mitochondria dynamically regulates the rate of ATP production [82]. Mitochondria link $\mathrm{Ca}^{2+}$ transport processes to the cellular metabolic state and affect the entire cellular network of $\mathrm{Ca}^{2+}$ signaling [83]. Mitochondrial $\mathrm{Ca}^{2+}$ modulates a number of $\mathrm{Ca}^{2+}$-dependent proteins and enzymes, to which many cellular activities and physiological and pathophysiological processes are related [17,84,85].

The mitochondrial $\mathrm{Ca}^{2+}$ influx is mainly mediated by the voltage-dependent anionselective channel (VDAC), mitochondrial calcium uniporter (MCU) and mitochondrial ryanodine receptor (mRYR) transporter. The VDAC is a member of the $\beta$-barrel membrane protein family, which is ubiquitous on the MOM of mammals [86,87]. It allows $\mathrm{Ca}^{2+}$ and other small molecular solutes in and out and is essential for $\mathrm{Ca}^{2+}$ transport between the cytoplasm and the mitochondrial membrane space $[24,88]$. However, the control and regulation of mitochondrial $\mathrm{Ca}^{2+}$ concentration is primarily on the MIM. The MCU is a mitochondrial calcium selective channel that regulates the balance of $\mathrm{Ca}^{2+}$ concentration between the cytoplasm and the mitochondrial matrix, thereby preventing excessive or insufficient calcium intake into the mitochondria $[25,89,90]$. In order to prevent detrimental $\mathrm{Ca}^{2+}$ overload, the activity of MCU must be tightly regulated [91]. The MCU-mediated $\mathrm{Ca}^{2+}$ uptake is driven by the inner membrane potential produced by the electron-transport chain (ETC) [92]. MCU channels are closed when $\mathrm{Ca}^{2+}$ is in equilibrium and activated when the concentration of $\mathrm{Ca}^{2+}$ in cytoplasm elevates $[93,94]$. Interestingly, the mRYR is also involved in mitochondrial $\mathrm{Ca}^{2+}$ influx, the dysregulation of which causes the onset of mitochondrial retrograde signaling in mouse and human cell lines [26,95]. 
The mitochondrial $\mathrm{Ca}^{2+}$ efflux pathways mainly include mitochondrial $\mathrm{Ca}^{2+} / \mathrm{H}^{+}$antiporter, $\mathrm{Na}^{+} / \mathrm{Ca}^{2+}$ exchanger and mitochondrial permeability transition pore (mPTP). Letm1, a mitochondrial inner membrane protein, has been identified as a mitochondrial $\mathrm{Ca}^{2+} / \mathrm{H}^{+}$antiporter, which is essential for normal glucose metabolism and alters brain function in Wolf-Hirschhorn syndrome mouse models $[27,96,97]$. The NCLX is an essential component of mitochondrial $\mathrm{Na}^{+} / \mathrm{Ca}^{2+}$ exchanger, which plays a fundamental role in regulating mitochondrial $\mathrm{Ca}^{2+}$ homeostasis $[28,98]$. The $\mathrm{mPTP}$ is a transmembrane protein residing on the MIM which can be induced by excessive $\mathrm{Ca}^{2+}$ in the mitochondrial matrix $[29,99]$. In turn, the mPTP leads to the collapse of the mitochondrial transmembrane potential and induces $\mathrm{Ca}^{2+}$ to release nonspecifically from the mitochondrial matrix to the cytoplasm, which is called "calcium-induced calcium release". Thus, the mitochondrial $\mathrm{Ca}^{2+}$ uptake should be strictly regulated to maintain a low matrix $\mathrm{Ca}^{2+}$ concentration that meets the dynamic cellular energy requirements and prevents mPTP from opening [92].

Mitochondrial $\mathrm{Ca}^{2+}$ transport participates in OXPHOS, tricarboxylic acid cycle, fatty acid metabolism and apoptosis related to the pathogenesis of some diseases [17,100-103]. Generally, the influx and efflux rates of $\mathrm{Ca}^{2+}$ in mitochondria are in balance, while the imbalance of mitochondrial $\mathrm{Ca}^{2+}$ homeostasis results in a series of changes in the physiological state of cells and diseases. For example, a study has indicated the crosstalk between mitochondrial $\mathrm{Ca}^{2+}$ uptake and autophagy in skeletal muscle [104]. Excessive $\mathrm{Ca}^{2+}$ within mitochondria can induce apoptosis by mPTP [105]. The reduced mitochondrial $\mathrm{Ca}^{2+}$ overload under pro-apoptotic stimuli significantly alleviated the apoptotic response [106]. Mitochondrial $\mathrm{Ca}^{2+}$ is also involved in insulin signaling [107]. The dysregulation of mitochondrial $\mathrm{Ca}^{2+}$ influx and efflux can disrupt intracellular $\mathrm{Ca}^{2+}$ homeostasis, which leads to insulin resistance and T2D in humans and animals [17]. By regulating mitochondrial calcium handling can alleviate diabetes-related cardiac disease [30]. It has been reported that insufficient mitochondrial $\mathrm{Ca}^{2+}$ uptake or $\mathrm{Ca}^{2+}$ overload contributes to heart failure, ischemia, reperfusion injury, brain aging, and neurodegenerative disease (e.g., Huntington's disease, Parkinson's disease and Alzheimer's disease) [20,31-35,108]. Targeting mitochondrial calcium has been considered a potential treatment against Parkinson's disease [109]. The loss of NCLX is a new driver of metastasis, and the regulation of mitochondrial $\mathrm{Ca}^{2+}$ is a novel therapeutic approach in human metastatic colorectal cancer [36]. Hopefully, mitochondrial $\mathrm{Ca}^{2+}$ transport will become potentially attractive targets for the development of novel therapeutic strategies.

\section{Mitochondrial $\mathrm{K}^{+}$}

A very significant role of $\mathrm{K}^{+}$in mitochondria is to maintain volume homeostasis and prevent excessive swelling or contraction of the mitochondrial matrix [110]. The intramitochondrial $\mathrm{K}^{+}$concentration is greater than the cytosolic $\mathrm{K}^{+}$concentration in neurons, suggesting that there must be $\mathrm{K}^{+}$channels/transporters between the mitochondria and cytoplasm [111]. Not surprisingly, it has been discovered that mitochondrial $\mathrm{K}^{+}$transport channels including mitochondrial ATP-sensitive $\mathrm{K}^{+}$(mitoKATP) channels, $\mathrm{Ca}^{2+}$-activated $\mathrm{K}^{+}(\mathrm{KCa})$ channels, voltage-gated $\mathrm{K}^{+}(\mathrm{Kv})$ channels, and TWIK-related acid-sensitive $\mathrm{K}^{+}$ channel 3 (mitoTASK-3) are located on the MIM [37-41]. The functions of these $\mathrm{K}^{+}$channels involve regulating mitochondrial respiration, maintaining membrane potential, and producing ROS [112]. Enhanced mitochondrial $\mathrm{K}^{+}$influx can induce cardioprotection and also protect against different forms of cell damage and death in different tissues [113-115].

The MitoKATP channel, as a highly selective conductor of $\mathrm{K}^{+}$, is an important factor in controlling mitochondrial and cellular physiology. Abundant MitoKATP channels respond to the cellular energetic status by regulating organelle volume and function [116]. MitoKATP channels have potential effects on multiple pathological processes, such as improving cardiac function, inhibiting apoptosis in diabetic cardiomyopathy, preventing ischemia and brain reperfusion injury, and protecting against partial rhythm disorders [44-47]. The protective role of MitoKATP channels is also found in temporal lobe epilepsy through the regulation of mitochondrial dynamic proteins in a rat model [43]. 
In addition, MitoKATP channels promote the proliferation of hypoxic human pulmonary artery smooth muscle cells and have an important role in the development of hypoxic pulmonary artery hypertension in animal models, which may become a target for disease treatment [23,48].

KCa channels open at the physiological inner membrane potential depending on the concentration of $\mathrm{Ca}^{2+}$ and selectively transport $\mathrm{K}^{+}$[117]. In the cardiovascular system, $\mathrm{KCa}$ channels are considered to be key mediators that control vascular tone and blood pressure by modulating the membrane potential and shaping $\mathrm{Ca}^{2+}$-dependent contraction [118]. The KCa channel opener NS-1619 has been shown to prevent the heart from being affected by global ischemia and reperfusion in mice $[119,120]$. In addition, KCa channels have emerged as a potential therapeutic tool for aging and age-related neurodegeneration [49]. $\mathrm{Kv}$ channels involve a variety of physiological processes ranging from triggering neuronal and cardiac action potential to regulating cell cycle and cell volume, to driving cellular proliferation and migration $[16,50]$. These $\mathrm{Kv}$ channels have a major role in human diseases such as cancer, schizophrenia, epilepsy, and sudden cardiac death $[50,51,53]$. In recent years, emerging evidence demonstrates that the $\mathrm{Kv}$ channel is becoming an oncological target since targeting it can reduce tumor growth and progression in vitro and in vivo [52,121-123]. Another $\mathrm{K}^{+}$influx channel, mitoTASK-3, whose function may be involved in ROS production and apoptosis, needs to be further understood [124,125]. Notably, recent research results point out that mitoTASK-3 has an effect on mitochondrial physiology, cancer cell survival and migration, and is a potential therapeutic target [126].

In turn, the $\mathrm{K}^{+}$efflux is conducted through a mitochondrial $\mathrm{K}^{+} / \mathrm{H}^{+}$exchanger (KHE), which is activated with the expansion of mitochondrial volume, preventing excess matrix swelling [42,127]. The defect of KHE can lead to increased matrix $\mathrm{K}^{+}$content, swelling, and attenuation of autophagy [128]. Compared with $\mathrm{K}^{+}$influx channels/transporters, the number of mitochondrial $\mathrm{K}^{+}$efflux channels/transporters that have been reported is extremely limited (Table 1 ), which is not conducive to the study of mitochondrial $\mathrm{K}^{+}$ homeostasis and related diseases and requires more attention.

\section{Mitochondrial $\mathrm{Na}^{+}$}

A recent study has revealed that $\mathrm{Na}^{+}$controls OXPHOS function and redox signal transduction through unexpected interactions with phospholipids and has a profound impact on cell metabolism [129]. Mitochondria in living cells keep low $\mathrm{Na}^{+}$levels despite the large electrochemical gradient favoring cation influx into the matrix, suggesting a complex transport mechanism is involved [130]. There is already evidence that mitochondrial $\mathrm{Na}^{+}$ transients are governed by the mitochondrial $\mathrm{Na}^{+} / \mathrm{H}^{+}$exchanger (NHE), which mediates mitochondrial $\mathrm{Na}^{+}$efflux [56]. The $\mathrm{Na}^{+}$spiking activity is significantly inhibited by mitochondrial NHE inhibition and is sensitive to cellular $\mathrm{pH}$ and $\mathrm{Na}^{+}$concentrations [130]. On the contrary, the $\mathrm{Na}^{+}$influx into the mitochondria is primarily mediated by the mitochondrial $\mathrm{Na}^{+} / \mathrm{Ca}^{2+}$ exchanger (NCLX) $[54,55]$. An elevated $\mathrm{Na}^{+}$concentration promotes mitochondrial $\mathrm{Ca}^{2+}$ efflux via NCLX [131]. In fact, mitochondrial $\mathrm{Na}^{+}$influx through NCLX could be potentially counter-balanced by the activity of a mitochondrial NHE. The NCLX is essential for cardiac survival and knockout of NCLX leads to heart failure in mice [18]. Another study shows that inhibition of the $\mathrm{Na}^{+} / \mathrm{Ca}^{2+}$ exchanger can prevent sudden death in a guinea pig model [57]. In addition, the mitochondrial NCLX, as a novel therapeutic target, also plays a role in a variety of neurodegenerative disorders [35].

\section{Mitochondrial $\mathrm{Mg}^{2+}$}

Mitochondria are believed to be responsible for cellular $\mathrm{Mg}^{2+}$ homeostasis [64]. The metabolism and productivity of mitochondria may lead to dynamic changes in $\mathrm{Mg}^{2+}$, which plays a vital role in the respiratory system $[132,133]$. Not only can mitochondria accumulate $\mathrm{Mg}^{2+}$, but also release $\mathrm{Mg}^{2+}$. Changes in mitochondrial $\mathrm{Mg}^{2+}$ concentration affect $\mathrm{Mg}^{2+}$-sensitive matrix enzymes (e.g., pyruvate dehydrogenase) and transporters (e.g., $\mathrm{Ca}^{2+}$ uniporter) on the MIM [134]. The $\mathrm{Mg}^{2+}$ concentration, remarkably constant and low 
in cytoplasm but tenfold higher in mitochondria, mediates ADP/ATP exchange between the cytosol and the matrix [135]. $\mathrm{Mg}^{2+}$ and ATP form a stable Mg-ATP complex, and the degree of complex formation depends on the ratio of $\mathrm{Mg}^{2+}$ to ATP [136]. Since $\mathrm{Mg}-\mathrm{ATP}$ is in a balanced state with free $\mathrm{Mg}^{2+}$ in cells, it has been suggested that a decrease in free $\mathrm{Mg}^{2+}$ may be a primary cause of low intracellular ATP [137]. The $\mathrm{Mg}^{2+}$ concentration needs to be adjusted to equilibrate any changes in rapidly available free energy [138]. $\mathrm{Mg}^{2+}$ participates in the release of Cytochrome $\mathrm{C}$, and the concentration of $\mathrm{Mg}^{2+}$ in the cytoplasm of apoptotic cells is also significantly increased in vitro $[139,140]$. However, in human colon cancer cells, intracellular $\mathrm{Mg}^{2+}$ content decreases during mitochondria-mediated apoptosis [141]. Regardless of this controversy, it is certain that there is a close relationship between $\mathrm{Mg}^{2+}$ homeostasis and apoptosis. In short, the effects of $\mathrm{Mg}^{2+}$ on mitochondrial functions mainly focus on energy metabolism, mitochondrial $\mathrm{Ca}^{2+}$ processing and apoptosis [139].

It has been found that the $\mathrm{Mg}^{2+}$ transporter of MRS2 (mitochondrial RNA splicing protein 2) on the MIM is an essential component of the mitochondrial $\mathrm{Mg}^{2+}$ uptake system which can selectively transport $\mathrm{Mg}^{2+}[58,59,133]$. The MRS2 channel seems to be involved in apoptosis, and its expression is related to the $\mathrm{Mg}^{2+}$ content inside the cells and mitochondria [142,143]. In fact, in vitro experiments conducted on human cells of conditional knockdown and overexpression of MRS2 channels induce cell death or lead to a minor susceptibility to apoptotic pharmacological insults [142,143]. Moreover, mitochondria-mediated apoptosis is linked to the multidrug-resistant (MDR) phenotype and gastric cancer, and the function of human MRS2 protein may be a promising target for MDR reversal therapy [65]. There is also a report showing that a mutation in the gene encoding mitochondrial $\mathrm{Mg}^{2+}$ channel MRS2 results in demyelination in rats [63]. Rats with MRS2 defect exhibit severe rapid myelin breakdown throughout the central nervous system [144]. Another two mitochondrial $\mathrm{Mg}^{2+}$ transporters, namely the mitochondrial $\mathrm{Mg}^{2+}$ efflux system SLC41A3 and the mitochondrial carrier protein Mme1, export $\mathrm{Mg}^{2+}$ into the cytoplasm and work together with mitochondrial importers to accurately regulate $\mathrm{Mg}^{2+}$ homeostasis [60-62]. In living cells, once mitochondrial $\mathrm{Mg}^{2+}$ homeostasis is out of balance, ATP production will be disrupted via a shift in mitochondrial energy metabolism and morphology [133]. Moreover, the perturbation of $\mathrm{Mg}^{2+}$ in cells and mitochondria has been shown to be involved in the neurodegenerative process of Parkinson's disease in cell models [64].

\section{Mitochondrial $\mathrm{Zn}^{2+}$}

The $\mathrm{Zn}^{2+}$ level is the most abundant in mitochondria compared with in other subcellular compartments [145]. $\mathrm{Zn}^{2+}$ plays an important role in maintaining mitochondrial function, and the dynamic balance of $\mathrm{Zn}^{2+}$ in mitochondria is necessary for normal cell metabolism. Zinc is thought to be beneficial in protecting mitochondrial antioxidants and ETC enzymes [146]. Movement of $\mathrm{Zn}^{2+}$ between cytosolic and mitochondrial pools might be of functional significance in intact neurons [147]. $\mathrm{Zn}^{2+}$ accumulates in neurons after ischemia and induces mitochondrial dysfunction and cell death [148,149]. Overloading of cellular or intramitochondrial $\mathrm{Zn}^{2+}$ will lose mitochondrial membrane potential, enhance ROS production and reduce cellular ATP levels [150,151]. Therefore, it is very important to study $\mathrm{Zn}^{2+}$ transport between cytosol and mitochondria. Some studies have indicated that $\mathrm{Zn}^{2+}$ is transported into mitochondria through MCU and suggested that $\mathrm{Zn}^{2+}$ is a critical contributor to mitochondrial dysfunction and ischemic neurodegeneration [66-68]. In MCU knockout mice, mitochondrial $\mathrm{Zn}^{2+}$ accumulation is significantly reduced [66]. $\mathrm{Ca}^{2+}$ may markedly increase the permeability of $\mathrm{MCU}$ to $\mathrm{Zn}^{2+}$, which has a synergistic effect [152]. It is inferred that the co-regulatory proteins MICU1 and MICU2, regulating mitochondrial $\mathrm{Ca}^{2+}$, also indirectly affect $\mathrm{Zn}^{2+}$ transport by MCU. In addition, two studies propose that mitochondrial SLC30A4 (Zinc transporter 4, ZnT4) transports $\mathrm{Zn}^{2+}$ from the cytosol to mitochondria, while mitochondrial SLC39A8 (ZIP8) transports $\mathrm{Zn}^{2+}$ from mitochondria to the cytosol $[69,70]$. In a rat model of alcohol-induced hepatic zinc deficiency, both SLC30A4 and SLC39A8 expression levels are observed to increase. Another report 
suggests that mitoKATP may be the main gate for the release of increased free $\mathrm{Zn}^{2+}$ from within the mitochondria in PC12 cell line [71]. Nevertheless, the transport mechanism of mitochondrial $\mathrm{Zn}^{2+}$ still needs more supporting evidence.

\section{Mitochondrial Iron Ion}

Mitochondria are the main utilization sites of iron which are transported to the matrix to synthesize iron-sulfur clusters and heme [153]. The precise regulation of iron ions in mitochondria is essential for hemoglobin production, Fe-S cluster protein assembly and heme biosynthesis during red blood cell development [78,154,155]. It is conceivable that mitochondrial iron homeostasis is involved in various hematological diseases. Mitochondrial iron homeostasis and its dysfunctions have been found in sideroblastic anemia and neurodegenerative disorders such as Alzheimer's disease, Parkinson's disease, Huntington disease, and Friedreich's ataxia [78-81]. Strikingly, iron overload is the primary cause of increased morbidity in thalassemia [156], but the current research on the relationship between mitochondrial iron homeostasis and thalassemia is very rare. In fact, abnormal cellular iron metabolism is largely affected by mitochondrial iron dyshomeostasis, which may lead to iron overload associated side effects. In turn, an iron loss induced by iron chelator triggers mitophagy [157].

MFRN (SLC25A37) belongs to the vertebrate mitochondrial solute carrier protein family, which transports various metabolites and cofactors on the MIM. Some researchers show that the MFRN is a carrier of iron ions into mitochondria, and mitochondria of MFRN mutants disrupt iron ion uptake, leading to severe hypochromic anemia and stagnant red blood cell maturation [72-75]. In mouse embryonic stem cells, the lack of MFRN causes fibroblasts to stop maturing and inhibits heme synthesis [72]. The disruption of yeast MFRN orthologs MRS3 and MRS4 leads to defects in iron metabolism and mitochondrial Fe-S cluster formation $[158,159]$. The transferrin/transferrin receptor 2 (Tf/TfR2) transport system has been reported to deliver transferrin-bound iron to mitochondria, which is disrupted in Parkinson's disease [76]. Another divalent metal transporter called DMT1 on the MOM also transports iron ions [77]. Overexpression of DMT1 is observed to increase the mitochondrial uptake of iron ions driven by proton gradients. Some small solutes and metal ions enter the mitochondrial membrane space through VDAC, which may involve iron uptake. Further research shows that VDAC is one of DMT1 interacting partners, and DMT1-VDAC interactions mediate mitochondrial iron uptake in cells [160]. Interestingly, mitochondrial ferritin (FTMT), as a novel iron-storage protein in mitochondria, participates in regulating iron distribution between cytosol and mitochondrial contents and has a protective effect in pathogenesis of neurodegenerative diseases in cell models [161,162]. It is worth noting that mitochondrial iron ion efflux channels/transporters have not yet been discovered, which requires an in-depth investigation (Table 1).

\section{Mitochondrial Manganese Ion}

Mitochondria are the main organelles producing ROS, the accumulation of which will cause cell toxicity, accelerated mutagenesis, lipid peroxidation, protein oxidation and cell death. Thus, the primary mechanism to eliminate ROS relies on superoxide dismutase (SOD), including the cytosolic copper/zinc-dependent SOD ( $\mathrm{Cu} / \mathrm{ZnSOD})$ and the mitochondrial manganese-dependent SOD (MnSOD) [163]. MnSOD is the only SOD isoform present in mitochondria, which requires a manganese ion as a cofactor to execute its antioxidant defense function [164]. At the cellular level, SLC39A8 (ZIP8) and SLC39A14 (ZIP14) have been identified to specifically mediate manganese uptake in mammals [165-167], while SLC30A10 (ZnT10) controls manganese efflux from cells [168,169]. However, the manganese ion transport mechanism in mitochondria is still unclear. It has been proposed that manganese ion uptake from cytosol to mitochondria is possibly mediated via MCU or MFRN1 [170]. Cells lacking MCU are more resistant to $\mathrm{Mn}^{2+}$ toxicity [171]. A potential role of mitochondria-localized SLC39A8 in the regulation of mitochondrial manganese ion transport will be an interesting point in future research. Of note, the po- 
tential role for altered $\mathrm{Mn}$ homeostasis and toxicity in neurodegenerative disorders has been reported, but whether it is related to mitochondrial manganese ion transport is still unknown [172-174].

\section{Other Mitochondrial Metal Ions}

Actually, there are more types of metal ions in mitochondria, not just those described above. With reference to the method of rapid immunopurification of mitochondria $[175,176]$, we isolated mitochondria from HepG2 cells and measured the content of different mitochondrial metal ions by inductively coupled plasma mass spectrometry (ICP-MS). This ICP-MS method has been reported to provide high accuracy in monitoring various metal ions $[177,178]$. As shown in Figure 2, our results demonstrate that the seven most abundant metal elements in mitochondria are $\mathrm{K}, \mathrm{Ca}, \mathrm{Na}, \mathrm{Mg}$, Fe, $\mathrm{Mn}$ and $\mathrm{Zn}$, whose mitochondrial transport channels and transporters have attracted great attention from researchers. So, their transport channels and transporters have been discovered more or less. However, $\mathrm{Al}, \mathrm{Cu}, \mathrm{Sn}, \mathrm{Ni}, \mathrm{Ba}$ and other metal ions whose abundances are closely followed and relatively low should also be considered seriously. On the one hand, what are the functions of these metal ions in mitochondria? Are they related to some mitochondrial diseases? On the other hand, how they are transported into and out of mitochondria? These questions have not yet been fully answered and require further investigation. For instance, aluminum is considered to be an inducer of the mitochondrial permeability transition [179], and aluminum phosphide can induce oxidative stress and mitochondrial damages in cardiomyocytes and isolated mitochondria [180]. Unfortunately, the transport of mitochondrial aluminum ions is still unclear. Another example is about mitochondrial copper ions. The study has found mitochondrial copper homeostasis and its derailment in Wilson disease [181]. Disruption of mitochondrial copper distribution inhibits self-renewal of leukemia stem cells [182]. More interestingly, it has recently been discovered that mitochondrial copper depletion can suppress triple-negative breast cancer [183]. These studies indicate that mitochondrial copper may be a potentially important and non-negligible target in therapy. However, mitochondrial copper ion transport is poorly understood. As for the lower contents of $\mathrm{Sn}, \mathrm{Ni}, \mathrm{Ba}$ and other metal ions, it is not yet clear how they are transported between the cytoplasm and the mitochondrial matrix. In brief, it is necessary to comprehensively investigate the transport of these mitochondrial metal ions in cell metabolism and diseases, which may become a potential target for the treatment of related diseases.
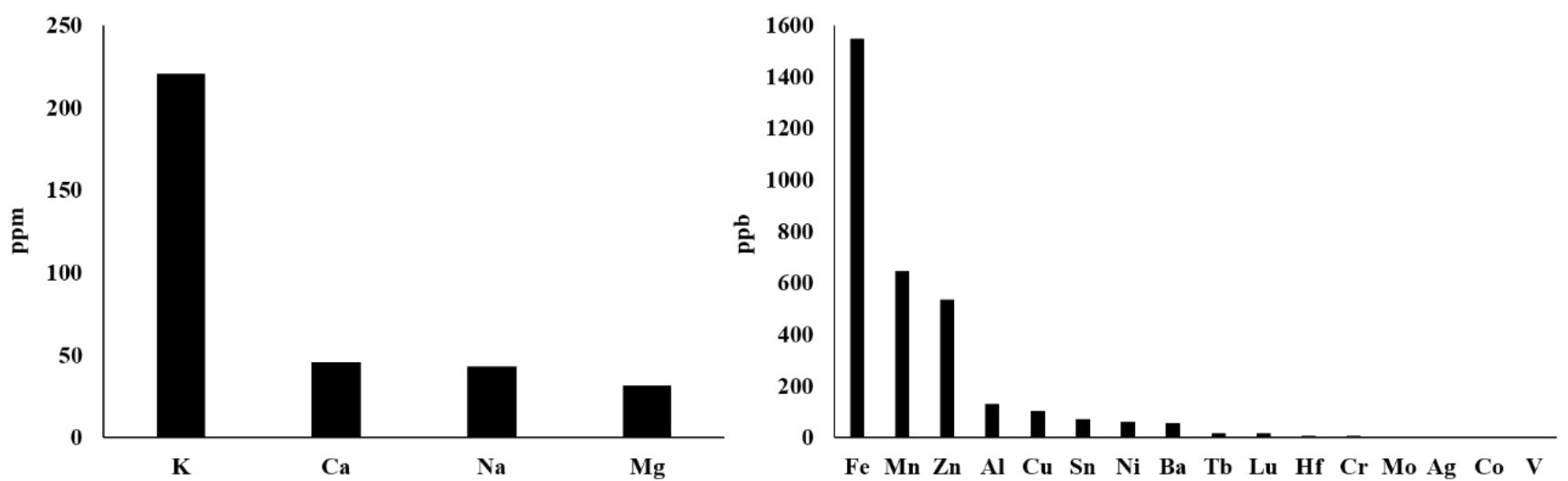

Figure 2. The contents of metal ions in mitochondria of HepG2 cells. The abundance decreases from left to right. HepG2 cells overexpressed the HA tag located on the MOM, and then mitochondria were quickly isolated using a HA-based magnetic bead (HA antibody-conjugated beads) system. After mitochondria were lysed, the abundance of metal ions was measured by ICP-MS. 


\section{Concluding Remarks and Prospects}

Under normal physiological conditions, the influx and efflux of mitochondrial metal ions are in dynamic equilibrium. Each channel/transporter transports metal ions at a very fast speed and generates huge electrochemical energy. In order to maintain the ATP content produced by the proton motive force, the opening probability of these metal ion channels and the number of metal ion channels/transporters of each mitochondrion must be tightly modulated to balance the influx and efflux of metal ions. Generally speaking, mitochondrial metal ion channels/transporters, with a significant role in energy supply, metabolic cycle, cell survival and death, are considered to be highly selective and strictly regulated. However, some metal ions in the matrix are not necessary for mitochondria, or their presence may be harmful, which are possible due to nonspecific transportation of certain metal ion channels/transporters.

As summarized in Table 1, there are different channels/transporters on the inner or outer membranes of mitochondria to transport various kinds of metal ions. The MCU can transport $\mathrm{Ca}^{2+}$ and $\mathrm{Zn}^{2+}$ from the cytoplasm to the mitochondrial matrix and may also participate in mitochondrial manganese ion uptake, indicating that MCU is not a specific metal ion transport channel. Interestingly, while NCLX mediates $\mathrm{Na}^{+}$influx into mitochondria, it can also export $\mathrm{Ca}^{2+}$ from the mitochondrial matrix to the cytoplasm. Increasing $\mathrm{Na}^{+}$level promotes mitochondrial $\mathrm{Ca}^{2+}$ efflux, which is an important mechanism to maintain the balance of $\mathrm{Na}^{+}-\mathrm{Ca}^{2+}$ in mitochondria. Therefore, if NCLX is mutated, it will cause the dyshomeostasis of both $\mathrm{Na}^{+}$and $\mathrm{Ca}^{2+}$. Similarly, mitoKATP not only transports $\mathrm{K}^{+}$into mitochondria, but also releases $\mathrm{Zn}^{2+}$ from the mitochondrial matrix into the cytoplasm. It is speculated that mitoKATP may regulate the balance of $\mathrm{K}^{+}-\mathrm{Zn}^{2+}$ in mitochondria. Surprisingly, no mitochondrial iron efflux channel/transporter has been discovered so far. Considering that most metal ions cannot be accumulated indefinitely in mitochondria, their corresponding efflux channels/transporters exist theoretically.

Actually, within mitochondria there may be other concentrations of metal ions (e.g., calcium) than in the cytoplasm, which is crucial for proper functioning of mitochondria as an organelle. Mitochondrial metal ions homeostasis plays an important role in health. Excessive metal ions mean dyshomeostasis, which affects cell metabolism and disease. Metal ions chelators have been reported to solve excess metal ions in cells, and are used in a range of applications. However, metal ion chelators applied to mitochondria are rare at present. Whether chelators acting on the cytoplasm can also regulate the homeostasis of mitochondrial metal ions remains to be further studied. The development of potential chelators that act on mitochondrial metal ions will be challenging and of great significance.

As is well known, mitochondria are essential for the metabolism of cells, which is closely related to disease and health. Abnormal cell metabolism, apoptosis or cell death caused by mitochondrial dysfunction can lead to serious and terrible adverse consequences. Since metal ion channels/transporters play important roles in keeping the normal functions of mitochondria and cells, if there is a problem in metal ion transportation, resulting in metal ions dyshomeostasis, it will cause a series of unhealthy cellular physiological states and numerous related diseases. Among related diseases caused by the dyshomeostasis of metal ions, neurodegeneration and cardiovascular diseases have been observed to be the most common (Table 1). We speculate this for at least two reasons: (1) Due to the high incidence and harmfulness of these two diseases, they have received more attention from scientific researchers. (2) The brain and heart need more energy and have a higher mitochondrial abundance than other organs. Once the mitochondrial function is impaired, the brain and heart are more prone to disease. Neurodegenerative diseases, in particular, are associated with most mitochondrial metal ions, suggesting the importance of exploring specific causes and targeted treatments.

Fortunately, mitochondrial metal ion transport is becoming an effective therapeutic target for some diseases such as T2D and cancer. However, the translational research of more channels/transporters in health and disease still has a long way to go. The current research on mitochondrial metal ion channels/transportations is insufficient, and the 
transport mechanism is not fully revealed. It should be emphasized that, as shown in Figure 2, there are more metal ions with relatively low abundance in mitochondria, but very little is known about their transports and functions. In different types of cells, the abundance of mitochondrial metal ions may also be different. Therefore, it is necessary to further explore the fields of mitochondrial metal ion channels/transports and provide a more detailed theoretical basis for the development of new strategies or drugs on treating related diseases. Up to now, at least 1000 nuclear-encoded genes located in mitochondria have been found, which definitely include all mitochondrial channel/transporter genes. More new discoveries about metal ion transports and related diseases could be expected through the large-scale knockout/knockdown or overexpression of these genes.

Funding: This work is supported by the Foundation of Beijing Advanced Innovation Center for Food Nutrition and Human Health, the National Natural Science Foundation of China (31970717) and the Chinese Universities Scientific Fund (2020TC015).

Conflicts of Interest: The authors declare no conflict of interest.

\begin{abstract}
Abbreviations
OXPHOS, oxidative phosphorylation; ATP, adenosine triphosphate; ROS, reactive oxygen species; MIM, mitochondrial inner membrane; MOM, mitochondrial outer membrane; T2D, type 2 diabetes; VDAC, voltage-dependent anion-selective channel; MCU, mitochondrial calcium uniporter; mRYR, mitochondrial ryanodine receptor; ETC, electron-transport chain; $\mathrm{MPTP}$, mitochondrial permeability transition pore; mitoKATP, mitochondrial ATP-sensitive $\mathrm{K}^{+}$channel; $\mathrm{KCa}$, $\mathrm{Ca}^{2+}$-activated $\mathrm{K}^{+}$channel; $\mathrm{Kv}$, voltage-gated $\mathrm{K}^{+}$channel; mitoTASK-3, TWIK-related acid-sensitive $\mathrm{K}^{+}$channel 3; $\mathrm{KHE}, \mathrm{K}^{+} / \mathrm{H}^{+}$ exchanger; NHE, $\mathrm{Na}^{+} / \mathrm{H}^{+}$exchanger; $\mathrm{NCLX}, \mathrm{Na}^{+} / \mathrm{Ca}^{2+}$ exchanger; MRS2, mitochondrial RNA splicing protein 2; Tf/TfR2, transferrin/transferrin receptor 2; SOD, superoxide dismutase; ICP-MS, inductively coupled plasma mass spectrometry.
\end{abstract}

\title{
References
}

1. Kauppila, T.E.S.; Kauppila, J.H.K.; Larsson, N.G. Mammalian Mitochondria and Aging: An Update. Cell Metab. $2017,25,57-71$. [CrossRef]

2. Spinelli, J.B.; Haigis, M.C. The multifaceted contributions of mitochondria to cellular metabolism. Nat. Cell Biol. 2018, 20, 745-754. [CrossRef]

3. Shadel, G.S.; Horvath, T.L. Mitochondrial ROS signaling in organismal homeostasis. Cell 2015, 163, 560-569. [CrossRef] [PubMed]

4. Marchi, S.; Patergnani, S.; Missiroli, S.; Morciano, G.; Rimessi, A.; Wieckowski, M.R.; Giorgi, C.; Pinton, P. Mitochondrial and endoplasmic reticulum calcium homeostasis and cell death. Cell Calcium 2018, 69, 62-72. [CrossRef] [PubMed]

5. Miller, W.L. Steroid hormone synthesis in mitochondria. Mol. Cell. Endocrinol. 2013, 379, 62-73. [CrossRef] [PubMed]

6. O'Rourke, B. Mitochondrial ion channels. Annu. Rev. Physiol. 2007, 69, 19-49. [CrossRef]

7. Passarella, S.; Atlante, A.; Valenti, D.; de Bari, L. The role of mitochondrial transport in energy metabolism. Mitochondrion 2003, 2, 319-343. [CrossRef]

8. Lemeshko, S.V.; Lemeshko, V.V. Metabolically derived potential on the outer membrane of mitochondria: A computational model. Biophys. J. 2000, 79, 2785-2800. [CrossRef]

9. De Marchi, U.; Fernandez-Martinez, S.; de la Fuente, S.; Wiederkehr, A.; Santo-Domingo, J. Mitochondrial ion channels in pancreatic Beta-Cells: Novel pharmacological targets for the treatment of Type 2 diabetes. Br. J. Pharmacol. 2020, 178, $2077-2095$. [CrossRef] [PubMed]

10. O'Rourke, B.; Cortassa, S.; Aon, M.A. Mitochondrial ion channels: Gatekeepers of life and death. Physiology 2005, 20, 303-315. [CrossRef]

11. Xia, M.; Zhang, Y.; Jin, K.; Lu, Z.; Zeng, Z.; Xiong, W. Communication between mitochondria and other organelles: A brand-new perspective on mitochondria in cancer. Cell Biosci. 2019, 9, 27. [CrossRef]

12. Nam, E.; Han, J.; Suh, J.M.; Yi, Y.; Lim, M.H. Link of impaired metal ion homeostasis to mitochondrial dysfunction in neurons Curr. Opin. Chem. Biol. 2018, 43, 8-14. [CrossRef] [PubMed]

13. Pierrel, F.; Cobine, P.A.; Winge, D.R. Metal Ion availability in mitochondria. Biometals Int. J. Role Met. Ions Biol. Biochem. Med. 2007, 20, 675-682. [CrossRef] [PubMed]

14. Matak, P.; Matak, A.; Moustafa, S.; Aryal, D.K.; Benner, E.J.; Wetsel, W.; Andrews, N.C. Disrupted iron homeostasis causes dopaminergic neurodegeneration in mice. Proc. Natl. Acad. Sci. USA 2016, 113, 3428-3435. [CrossRef] [PubMed] 
15. Horowitz, M.P.; Greenamyre, J.T. Mitochondrial iron metabolism and its role in neurodegeneration. J. Alzheimer's Dis. JAD 2010, 20, S551-S568. [CrossRef]

16. Wang, W.; Fan, Y.; Wang, S.; Wang, L.; He, W.; Zhang, Q.; Li, X. Effects of voltage-gated K+ channel on cell proliferation in multiple myeloma. Sci. World J. 2014, 2014, 785140. [CrossRef] [PubMed]

17. Wang, C.H.; Wei, Y.H. Role of mitochondrial dysfunction and dysregulation of $\mathrm{Ca}(2+)$ homeostasis in the pathophysiology of insulin resistance and type 2 diabetes. J. Biomed. Sci. 2017, 24, 70. [CrossRef]

18. Ummarino, D. Calcium: Mitochondrial calcium efflux essential for heart function. Nat. Rev. Cardiol. 2017, 14, 317. [CrossRef]

19. Williams, G.S.; Boyman, L.; Lederer, W.J. Mitochondrial calcium and the regulation of metabolism in the heart. J. Mol. Cell. Cardiol. 2015, 78, 35-45. [CrossRef]

20. Wang, W.; Karamanlidis, G.; Tian, R. Novel targets for mitochondrial medicine. Sci. Transl. Med. 2016, 8, 326rv3. [CrossRef] [PubMed]

21. Bachmann, M.; Costa, R.; Peruzzo, R.; Prosdocimi, E.; Checchetto, V.; Leanza, L. Targeting Mitochondrial Ion Channels to Fight Cancer. Int. J. Mol. Sci. 2018, 19, 2060. [CrossRef]

22. Tajti, G.; Wai, D.C.C.; Panyi, G.; Norton, R.S. The Voltage-Gated potassium channel KV1.3 as a therapeutic target for venomderived peptides. Biochem. Pharmacol. 2020, 181, 114146. [CrossRef] [PubMed]

23. Dong, L.; Li, Y.; Hu, H.; Shi, L.; Chen, J.; Wang, B.; Chen, C.; Zhu, H.; Li, Y.; Li, Q.; et al. Potential therapeutic targets for hypoxia-induced pulmonary artery hypertension. J. Transl. Med. 2014, 12, 39. [CrossRef] [PubMed]

24. Shoshan-Barmatz, V.; Israelson, A.; Brdiczka, D.; Sheu, S.S. The Voltage-Dependent anion channel (VDAC): Function in intracellular signalling, cell life and cell death. Curr. Pharm. Des. 2006, 12, 2249-2270. [CrossRef]

25. Baughman, J.M.; Perocchi, F.; Girgis, H.S.; Plovanich, M.; Belcher-Timme, C.A.; Sancak, Y.; Bao, X.R.; Strittmatter, L.; Goldberger, O.; Bogorad, R.L.; et al. Integrative genomics identifies MCU as an essential component of the mitochondrial calcium uniporter. Nature 2011, 476, 341-345. [CrossRef] [PubMed]

26. Roy Chowdhury, A.; Srinivasan, S.; Csordas, G.; Hajnoczky, G.; Avadhani, N.G. Dysregulation of RyR Calcium Channel Causes the Onset of Mitochondrial Retrograde Signaling. iScience 2020, 23, 101370. [CrossRef]

27. Jiang, D.; Zhao, L.; Clapham, D.E. Genome-Wide RNAi screen identifies Letm1 as a mitochondrial Ca ${ }^{2+} / \mathrm{H}^{+}$antiporter. Science 2009, 326, 144-147. [CrossRef]

28. Palty, R.; Silverman, W.F.; Hershfinkel, M.; Caporale, T.; Sensi, S.L.; Parnis, J.; Nolte, C.; Fishman, D.; Shoshan-Barmatz, V.; Herrmann, S.; et al. NCLX is an essential component of mitochondrial $\mathrm{Na}^{+} / \mathrm{Ca}^{2+}$ exchange. Proc. Natl. Acad. Sci. USA 2010, 107, 436-441. [CrossRef] [PubMed]

29. Huang, X.; Zhai, D.; Huang, Y. Study on the relationship between calcium-induced calcium release from mitochondria and PTP opening. Mol. Cell. Biochem. 2000, 213, 29-35. [CrossRef] [PubMed]

30. Diaz-Juarez, J.; Suarez, J.A.; Dillmann, W.H.; Suarez, J. Mitochondrial calcium handling and heart disease in diabetes mellitus. Biochim. Biophys. Acta Mol. Basis Dis. 2021, 1867, 165984. [CrossRef]

31. Xu, H.X.; Cui, S.M.; Zhang, Y.M.; Ren, J. Mitochondrial Ca(2+) regulation in the etiology of heart failure: Physiological and pathophysiological implications. Acta Pharmacol. Sin. 2020, 41, 1301-1309. [CrossRef]

32. Jung, H.; Kim, S.Y.; Canbakis Cecen, F.S.; Cho, Y.; Kwon, S.K. Dysfunction of Mitochondrial Ca(2+) Regulatory Machineries in Brain Aging and Neurodegenerative Diseases. Front. Cell Dev. Biol. 2020, 8, 599792. [CrossRef]

33. Naia, L.; Ferreira, I.L.; Ferreiro, E.; Rego, A.C. Mitochondrial Ca(2+) handling in Huntington's and Alzheimer's Diseases-Role of ER-Mitochondria crosstalk. Biochem. Biophys. Res. Commun. 2017, 483, 1069-1077. [CrossRef]

34. Jadiya, P.; Kolmetzky, D.W.; Tomar, D.; Di Meco, A.; Lombardi, A.A.; Lambert, J.P.; Luongo, T.S.; Ludtmann, M.H.; Pratico, D.; Elrod, J.W. Impaired mitochondrial calcium efflux contributes to disease progression in models of Alzheimer's disease. Nat. Commun. 2019, 10, 3885. [CrossRef]

35. Ludtmann, M.H.R.; Abramov, A.Y. Mitochondrial calcium imbalance in Parkinson's disease. Neurosci. Lett. 2018, 663, 86-90. [CrossRef] [PubMed]

36. Pathak, T.; Gueguinou, M.; Walter, V.; Delierneux, C.; Johnson, M.T.; Zhang, X.; Xin, P.; Yoast, R.E.; Emrich, S.M.; Yochum, G.S.; et al. Dichotomous role of the human mitochondrial $\mathrm{Na}(+) / \mathrm{Ca} 2(+) / \mathrm{Li}(+)$ exchanger $\mathrm{NCLX}$ in colorectal cancer growth and metastasis. eLife 2020, 9, e59686. [CrossRef] [PubMed]

37. Inoue, I.; Nagase, H.; Kishi, K.; Higuti, T. ATP-sensitive K+ channel in the mitochondrial inner membrane. Nature 1991, 352, 244-247. [CrossRef] [PubMed]

38. Jensen, M.O.; Jogini, V.; Borhani, D.W.; Leffler, A.E.; Dror, R.O.; Shaw, D.E. Mechanism of voltage gating in potassium channels. Science 2012, 336, 229-233. [CrossRef] [PubMed]

39. Berkefeld, H.; Fakler, B.; Schulte, U. Ca ${ }^{2+}$-activated $\mathrm{K}^{+}$channels: From protein complexes to function. Physiol. Rev. 2010, 90, 1437-1459. [CrossRef]

40. Bednarczyk, P.; Kowalczyk, J.E.; Beresewicz, M.; Dolowy, K.; Szewczyk, A.; Zablocka, B. Identification of a Voltage-Gated potassium channel in gerbil hippocampal mitochondria. Biochem. Biophys. Res. Commun. 2010, 397, 614-620. [CrossRef]

41. Rusznak, Z.; Bakondi, G.; Kosztka, L.; Pocsai, K.; Dienes, B.; Fodor, J.; Telek, A.; Gonczi, M.; Szucs, G.; Csernoch, L. Mitochondrial expression of the Two-Pore domain TASK-3 channels in malignantly transformed and non-malignant human cells. Virchows Arch. Int. J. Pathol. 2008, 452, 415-426. [CrossRef] 
42. Brierley, G.P.; Jurkowitz, M.S.; Farooqui, T.; Jung, D.W. K+/H+ antiport in heart mitochondria. J. Biol. Chem. 1984, 259, 14672-14678. [CrossRef]

43. Nikbakht, F.; Khanizadeh, A.M.; Golab, F.; Baluchnejadmojarad, T.; Vazifehkhah, S.; Moeinsadat, A. Mitochondrial ATP-sensitive potassium channel, MitoKATP, ameliorates mitochondrial dynamic disturbance induced by temporal lobe epilepsy. J. Chem. Neuroanat. 2020, 113, 101808. [CrossRef]

44. Krylova, I.B.; Kachaeva, E.V.; Rodionova, O.M.; Negoda, A.E.; Evdokimova, N.R.; Balina, M.I.; Sapronov, N.S.; Mironova, G.D. The cardioprotective effect of uridine and uridine-5'-monophosphate: The role of the mitochondrial ATP-Dependent potassium channel. Exp. Gerontol. 2006, 41, 697-703. [CrossRef] [PubMed]

45. Duan, P.; Wang, J.; Li, Y.; Wei, S.; Su, F.; Zhang, S.; Duan, Y.; Wang, L.; Zhu, Q. Opening of mitoKATP improves cardiac function and inhibits apoptosis via the AKT-Foxo1 signaling pathway in diabetic cardiomyopathy. Int. J. Mol. Med. 2018, 42, $2709-2719$. [CrossRef] [PubMed]

46. Peng, K.; Hu, J.; Xiao, J.; Dan, G.; Yang, L.; Ye, F.; Zou, Z.; Cao, J.; Sai, Y. Mitochondrial ATP-Sensitive potassium channel regulates mitochondrial dynamics to participate in neurodegeneration of Parkinson's disease. Biochim. Biophys. Acta Mol. Basis Dis. 2018, 1864, 1086-1103. [CrossRef]

47. Rameshrad, M.; Omidkhoda, S.F.; Razavi, B.M.; Hosseinzadeh, H. Evaluating the possible role of mitochondrial ATP-Sensitive potassium channels in the cardioprotective effects of morin in the isolated rat heart. Life Sci. 2021, 264, 118659. [CrossRef]

48. Hu, H.; Ding, Y.; Wang, Y.; Geng, S.; Liu, J.; He, J.; Lu, Y.; Li, X.; Yuan, M.; Zhu, S.; et al. MitoKATP channels promote the proliferation of hypoxic human pulmonary artery smooth muscle cells via the ROS/HIF/miR-210/ISCU signaling pathway. Exp. Ther. Med. 2017, 14, 6105-6112. [CrossRef] [PubMed]

49. Trombetta-Lima, M.; Krabbendam, I.E.; Dolga, A.M. Calcium-activated potassium channels: Implications for aging and agerelated neurodegeneration. Int. J. Biochem. Cell Biol. 2020, 123, 105748. [CrossRef]

50. Burton, M.J.; Cresser-Brown, J.; Thomas, M.; Portolano, N.; Basran, J.; Freeman, S.L.; Kwon, H.; Bottrill, A.R.; Llansola-Portoles, M.J.; Pascal, A.A.; et al. Discovery of a Heme-Binding domain in a neuronal Voltage-Gated potassium channel. J. Biol. Chem. 2020, 295, 13277-13286. [CrossRef]

51. Wulff, H.; Castle, N.A.; Pardo, L.A. Voltage-Gated potassium channels as therapeutic targets. Nat. Rev. Drug Discov. 2009, 8, 982-1001. [CrossRef] [PubMed]

52. Prosdocimi, E.; Checchetto, V.; Leanza, L. Targeting the Mitochondrial Potassium Channel Kv1.3 to Kill Cancer Cells: Drugs, Strategies, and New Perspectives. SLAS Discov. Adv. Life Sci. R D 2019, 24, 882-892. [CrossRef]

53. Wrzosek, A.; Augustynek, B.; Zochowska, M.; Szewczyk, A. Mitochondrial Potassium Channels as Druggable Targets. Biomolecules 2020, 10, 1200. [CrossRef]

54. Murphy, E.; Eisner, D.A. Regulation of intracellular and mitochondrial sodium in health and disease. Circ. Res. 2009, 104, 292-303. [CrossRef] [PubMed]

55. Nita, I.I.; Hershfinkel, M.; Kantor, C.; Rutter, G.A.; Lewis, E.C.; Sekler, I. Pancreatic beta-cell Na+ channels control global Ca ${ }^{2+}$ signaling and oxidative metabolism by inducing $\mathrm{Na}^{+}$and $\mathrm{Ca}^{2+}$ responses that are propagated into mitochondria. FASEB J. Off. Publ. Fed. Am. Soc. Exp. Biol. 2014, 28, 3301-3312.

56. Nita, I.I.; Hershfinkel, M.; Lewis, E.C.; Sekler, I. A crosstalk between $\mathrm{Na}(+)$ channels, $\mathrm{Na}(+) / \mathrm{K}(+)$ pump and mitochondrial $\mathrm{Na}(+)$ transporters controls Glucose-Dependent cytosolic and mitochondrial Na(+) signals. Cell Calcium 2015, 57, 69-75. [CrossRef] [PubMed]

57. Liu, T.; Takimoto, E.; Dimaano, V.L.; DeMazumder, D.; Kettlewell, S.; Smith, G.; Sidor, A.; Abraham, T.P.; O’Rourke, B. Inhibiting mitochondrial $\mathrm{Na}+/ \mathrm{Ca}^{2+}$ exchange prevents sudden death in a Guinea pig model of heart failure. Circ. Res. 2014, 115, 44-54. [CrossRef]

58. Schindl, R.; Weghuber, J.; Romanin, C.; Schweyen, R.J. Mrs2p forms a high conductance $\mathrm{Mg}^{2+}$ selective channel in mitochondria. Biophys. J. 2007, 93, 3872-3883. [CrossRef] [PubMed]

59. Moomaw, A.S.; Maguire, M.E. The unique nature of $\mathrm{mg}^{2+}$ channels. Physiology 2008, 23, 275-285. [CrossRef]

60. Mastrototaro, L.; Smorodchenko, A.; Aschenbach, J.R.; Kolisek, M.; Sponder, G. Solute carrier 41A3 encodes for a mitochondrial $\mathrm{Mg}(2+)$ efflux system. Sci. Rep. 2016, 6, 27999. [CrossRef]

61. Cui, Y.; Zhao, S.; Wang, X.; Zhou, B. A novel Drosophila mitochondrial carrier protein acts as a Mg(2+) exporter in fine-tuning mitochondrial $\mathrm{Mg}(2+)$ homeostasis. Biochim. Biophys. Acta 2016, 1863, 30-39. [CrossRef]

62. Cui, Y.; Zhao, S.; Wang, J.; Wang, X.; Gao, B.; Fan, Q.; Sun, F.; Zhou, B. A novel mitochondrial carrier protein Mme1 acts as a yeast mitochondrial magnesium exporter. Biochim. Biophys. Acta 2015, 1853, 724-732. [CrossRef] [PubMed]

63. Kuramoto, T.; Kuwamura, M.; Tokuda, S.; Izawa, T.; Nakane, Y.; Kitada, K.; Akao, M.; Guenet, J.L.; Serikawa, T. A mutation in the gene encoding mitochondrial $\mathrm{Mg}(2)+$ channel MRS2 results in demyelination in the rat. PLoS Genet. 2011, 7, e1001262. [CrossRef]

64. Shindo, Y.; Yamanaka, R.; Suzuki, K.; Hotta, K.; Oka, K. Intracellular magnesium level determines cell viability in the MPP(+) model of Parkinson's disease. Biochim. Biophys. Acta 2015, 1853, 3182-3191. [CrossRef] [PubMed]

65. Chen, Y.; Wei, X.; Yan, P.; Han, Y.; Sun, S.; Wu, K.; Fan, D. Human mitochondrial Mrs2 protein promotes multidrug resistance in gastric cancer cells by regulating p27, cyclin D1 expression and cytochrome C release. Cancer Biol. Ther. 2009, 8, 607-614. [CrossRef]

66. Ji, S.G.; Medvedeva, Y.V.; Weiss, J.H. Zn(2+) entry through the mitochondrial calcium uniporter is a critical contributor to mitochondrial dysfunction and neurodegeneration. Exp. Neurol. 2020, 325, 113161. [CrossRef] 
67. Medvedeva, Y.V.; Weiss, J.H. Intramitochondrial $\mathrm{Zn}^{2+}$ accumulation via the Ca2+ uniporter contributes to acute ischemic neurodegeneration. Neurobiol. Dis. 2014, 68, 137-144. [CrossRef] [PubMed]

68. Saris, N.E.; Niva, K. Is $\mathrm{Zn}^{2+}$ transported by the mitochondrial calcium uniporter? FEBS Lett. 1994, 356, 195-198. [CrossRef]

69. Besecker, B.; Bao, S.; Bohacova, B.; Papp, A.; Sadee, W.; Knoell, D.L. The human zinc transporter SLC39A8 (Zip8) is critical in zinc-mediated cytoprotection in lung epithelia. Am. J. Physiol. Lung Cell. Mol. Physiol. 2008, 294, L1127-L1136. [CrossRef]

70. Sun, Q.; Zhong, W.; Zhang, W.; Li, Q.; Sun, X.; Tan, X.; Sun, X.; Dong, D.; Zhou, Z. Zinc deficiency mediates Alcohol-Induced apoptotic cell death in the liver of rats through activating ER and mitochondrial cell death pathways. Am. J. Physiol. Gastrointest. Liver Physiol. 2015, 308, G757-G766. [CrossRef]

71. Yang, D.M.; Huang, C.C.; Chang, Y.F. Combinatorial roles of mitochondria and cGMP/PKG pathway in the generation of neuronal free $\mathrm{Zn}^{2+}$ under the presence of nitric oxide. JCMA 2020, 83, 357-366. [CrossRef]

72. Shaw, G.C.; Cope, J.J.; Li, L.; Corson, K.; Hersey, C.; Ackermann, G.E.; Gwynn, B.; Lambert, A.J.; Wingert, R.A.; Traver, D.; et al. Mitoferrin is essential for erythroid iron assimilation. Nature 2006, 440, 96-100. [CrossRef] [PubMed]

73. Zhao, L.; Xia, Z.; Wang, F. Zebrafish in the sea of mineral (iron, zinc, and copper) metabolism. Front. Pharmacol. 2014, 5, 33. [CrossRef]

74. Finoshin, A.D.; Adameyko, K.I.; Mikhailov, K.V.; Kravchuk, O.I.; Georgiev, A.A.; Gornostaev, N.G.; Kosevich, I.A.; Mikhailov, V.S.; Gazizova, G.R.; Shagimardanova, E.I.; et al. Iron metabolic pathways in the processes of sponge plasticity. PLoS ONE 2020, $15, \mathrm{e} 0228722$.

75. Seguin, A.; Jia, X.; Earl, A.M.; Li, L.; Wallace, J.; Qiu, A.; Bradley, T.; Shrestha, R.; Troadec, M.B.; Hockin, M.; et al. The mitochondrial metal transporters mitoferrin1 and mitoferrin2 are required for liver regeneration and cell proliferation in mice. $J$. Biol. Chem. 2020, 295, 11002-11020. [CrossRef]

76. Mastroberardino, P.G.; Hoffman, E.K.; Horowitz, M.P.; Betarbet, R.; Taylor, G.; Cheng, D.; Na, H.M.; Gutekunst, C.A.; Gearing, M.; Trojanowski, J.Q.; et al. A novel transferrin/TfR2-mediated mitochondrial iron transport system is disrupted in Parkinson's disease. Neurobiol. Dis. 2009, 34, 417-431. [CrossRef] [PubMed]

77. Wolff, N.A.; Garrick, M.D.; Zhao, L.; Garrick, L.M.; Ghio, A.J.; Thevenod, F. A role for divalent metal transporter (DMT1) in mitochondrial uptake of iron and manganese. Sci. Rep. 2018, 8, 211. [CrossRef] [PubMed]

78. Gao, J.; Zhou, Q.; Wu, D.; Chen, L. Mitochondrial iron metabolism and its role in diseases. Clin. Chim. Acta Int. J. Clin. Chem. 2021, 513, 6-12. [CrossRef]

79. Mena, N.P.; Urrutia, P.J.; Lourido, F.; Carrasco, C.M.; Nunez, M.T. Mitochondrial iron homeostasis and its dysfunctions in neurodegenerative disorders. Mitochondrion 2015, 21, 92-105. [CrossRef]

80. Urrutia, P.J.; Mena, N.P.; Nunez, M.T. The interplay between iron accumulation, mitochondrial dysfunction, and inflammation during the execution step of neurodegenerative disorders. Front. Pharmacol. 2014, 5, 38. [CrossRef]

81. Isaya, G. Mitochondrial iron-sulfur cluster dysfunction in neurodegenerative disease. Front. Pharmacol. 2014, 5, 29. [CrossRef]

82. Boyman, L.; Karbowski, M.; Lederer, W.J. Regulation of Mitochondrial ATP Production: Ca(2+) Signaling and Quality Control. Trends Mol. Med. 2020, 26, 21-39. [CrossRef]

83. Szabadkai, G.; Duchen, M.R. Mitochondria: The hub of cellular Ca ${ }^{2+}$ signaling. Physiology 2008, 23, 84-94. [CrossRef] [PubMed]

84. Sisalli, M.J.; Feliciello, A.; Della Notte, S.; Di Martino, R.; Borzacchiello, D.; Annunziato, L.; Scorziello, A. Nuclear-encoded NCX3 and AKAP121: Two novel modulators of mitochondrial calcium efflux in normoxic and hypoxic neurons. Cell Calcium 2020, 87, 102193. [CrossRef] [PubMed]

85. Dejos, C.; Gkika, D.; Cantelmo, A.R. The Two-Way Relationship Between Calcium and Metabolism in Cancer. Front. Cell Dev. Biol. 2020, 8, 573747. [CrossRef] [PubMed]

86. Forte, M.; Guy, H.R.; Mannella, C.A. Molecular genetics of the VDAC ion channel: Structural model and sequence analysis. J. Bioenerg. Biomembr. 1987, 19, 341-350. [CrossRef]

87. Paschen, S.A.; Waizenegger, T.; Stan, T.; Preuss, M.; Cyrklaff, M.; Hell, K.; Rapaport, D.; Neupert, W. Evolutionary conservation of biogenesis of beta-barrel membrane proteins. Nature 2003, 426, 862-866. [CrossRef]

88. Baines, C.P.; Kaiser, R.A.; Sheiko, T.; Craigen, W.J.; Molkentin, J.D. Voltage-Dependent anion channels are dispensable for mitochondrial-dependent cell death. Nat. Cell Biol. 2007, 9, 550-555. [CrossRef]

89. Rizzuto, R.; De Stefani, D.; Raffaello, A.; Mammucari, C. Mitochondria as sensors and regulators of calcium signalling. Nat. Rev. Mol. Cell Biol. 2012, 13, 566-578. [CrossRef]

90. Fan, C.; Fan, M.; Orlando, B.J.; Fastman, N.M.; Zhang, J.; Xu, Y.; Chambers, M.G.; Xu, X.; Perry, K.; Liao, M.; et al. X-ray and cryo-EM structures of the mitochondrial calcium uniporter. Nature 2018, 559, 575-579. [CrossRef]

91. Fan, M.; Zhang, J.; Tsai, C.W.; Orlando, B.J.; Rodriguez, M.; Xu, Y.; Liao, M.; Tsai, M.F.; Feng, L. Structure and mechanism of the mitochondrial $\mathrm{Ca}(2+)$ uniporter holocomplex. Nature 2020, 582, 129-133. [CrossRef] [PubMed]

92. Vais, H.; Payne, R.; Paudel, U.; Li, C.; Foskett, J.K. Coupled transmembrane mechanisms control MCU-mediated mitochondrial Ca(2+) uptake. Proc. Natl. Acad. Sci. USA 2020, 117, 21731-21739. [CrossRef]

93. Csordas, G.; Golenar, T.; Seifert, E.L.; Kamer, K.J.; Sancak, Y.; Perocchi, F.; Moffat, C.; Weaver, D.; Perez, S.F.; Bogorad, R.; et al. MICU1 controls both the threshold and cooperative activation of the mitochondrial Ca(2)(+) uniporter. Cell Metab. 2013, 17, 976-987. [CrossRef] [PubMed] 
94. Patron, M.; Raffaello, A.; Granatiero, V.; Tosatto, A.; Merli, G.; De Stefani, D.; Wright, L.; Pallafacchina, G.; Terrin, A.; Mammucari, C.; et al. The mitochondrial calcium uniporter (MCU): Molecular identity and physiological roles. J. Biol. Chem. 2013, 288, 10750-10758. [CrossRef]

95. Beutner, G.; Sharma, V.K.; Giovannucci, D.R.; Yule, D.I.; Sheu, S.S. Identification of a ryanodine receptor in rat heart mitochondria. J. Biol. Chem. 2001, 276, 21482-21488. [CrossRef] [PubMed]

96. Jiang, D.; Zhao, L.; Clish, C.B.; Clapham, D.E. Letm1, the mitochondrial $\mathrm{Ca}^{2+} / \mathrm{H}^{+}$antiporter, is essential for normal glucose metabolism and alters brain function in Wolf-Hirschhorn syndrome. Proc. Natl. Acad. Sci. USA 2013, 110, E2249-E2254. [CrossRef]

97. Tsai, M.F.; Jiang, D.; Zhao, L.; Clapham, D.; Miller, C. Functional reconstitution of the mitochondrial Ca ${ }^{2+} / \mathrm{H}^{+}$antiporter Letm1. J. Gen. Physiol. 2014, 143, 67-73. [CrossRef]

98. Belosludtsev, K.N.; Dubinin, M.V.; Belosludtseva, N.V.; Mironova, G.D. Mitochondrial Ca ${ }^{2+}$ Transport: Mechanisms, Molecular Structures, and Role in Cells. Biochem. Biokhimiia 2019, 84, 593-607. [CrossRef]

99. Huser, C.A.; Davies, M.E. Calcium signaling leads to mitochondrial depolarization in impact-induced chondrocyte death in equine articular cartilage explants. Arthritis Rheum. 2007, 56, 2322-2334. [CrossRef]

100. Vercesi, A.E.; Kowaltowski, A.J.; Oliveira, H.C.; Castilho, R.F. Mitochondrial Ca ${ }^{2+}$ transport, permeability transition and oxidative stress in cell death: Implications in cardiotoxicity, neurodegeneration and dyslipidemias. Front. Biosci. A J. Virtual Libr. 2006, 11, 2554-2564. [CrossRef] [PubMed]

101. Rossi, A.; Pizzo, P.; Filadi, R. Calcium, mitochondria and cell metabolism: A functional triangle in bioenergetics. Biochim. Biophys. Acta Mol. Cell Res. 2019, 1866, 1068-1078. [CrossRef] [PubMed]

102. Alevriadou, B.R.; Patel, A.; Noble, M.; Ghosh, S.; Gohil, V.M.; Stathopulos, P.B.; Madesh, M. Molecular nature and physiological role of the mitochondrial calcium uniporter channel. Am. J. Physiol. Cell Physiol. 2021, 320, C465-C482. [CrossRef] [PubMed]

103. Murphy, E.; Steenbergen, C. Regulation of Mitochondrial Ca(2+) Uptake. Annu. Rev. Physiol. 2021, 83, 107-126. [CrossRef]

104. Gherardi, G.; Di Marco, G.; Rizzuto, R.; Mammucari, C. Crosstalk between Mitochondrial Ca(2+) Uptake and Autophagy in Skeletal Muscle. Oxidative Med. Cell. Longev. 2019, 2019, 1845321. [CrossRef]

105. Chen, X.; Zhang, X.; Kubo, H.; Harris, D.M.; Mills, G.D.; Moyer, J.; Berretta, R.; Potts, S.T.; Marsh, J.D.; Houser, S.R. Ca ${ }^{2+}$ influx-induced sarcoplasmic reticulum $\mathrm{Ca}^{2+}$ overload causes mitochondrial-dependent apoptosis in ventricular myocytes. Circ. Res. 2005, 97, 1009-1017. [CrossRef]

106. Giorgi, C.; Baldassari, F.; Bononi, A.; Bonora, M.; De Marchi, E.; Marchi, S.; Missiroli, S.; Patergnani, S.; Rimessi, A.; Suski, J.M.; et al. Mitochondrial $\mathrm{Ca}(2+)$ and apoptosis. Cell calcium 2012, 52, 36-43. [CrossRef]

107. Gutierrez, T.; Parra, V.; Troncoso, R.; Pennanen, C.; Contreras-Ferrat, A.; Vasquez-Trincado, C.; Morales, P.E.; Lopez-Crisosto, C.; Sotomayor-Flores, C.; Chiong, M.; et al. Alteration in mitochondrial $\mathrm{Ca}(2+)$ uptake disrupts insulin signaling in hypertrophic cardiomyocytes. CCS 2014, 12, 68. [CrossRef] [PubMed]

108. O'Rourke, B.; Ashok, D.; Liu, T. Mitochondrial Ca(2+) in heart failure: Not enough or too much? J. Mol. Cell. Cardiol. 2021, 151, 126-134. [CrossRef]

109. Dey, K.; Bazala, M.A.; Kuznicki, J. Targeting mitochondrial calcium pathways as a potential treatment against Parkinson's disease. Cell Calcium 2020, 89, 102216. [CrossRef] [PubMed]

110. Garlid, K.D.; Paucek, P. Mitochondrial potassium transport: The K(+) cycle. Biochim. Biophys. Acta 2003, 1606, 23-41. [CrossRef]

111. Liu, D.; Slevin, J.R.; Lu, C.; Chan, S.L.; Hansson, M.; Elmer, E.; Mattson, M.P. Involvement of mitochondrial K+ release and cellular efflux in ischemic and apoptotic neuronal death. J. Neurochem. 2003, 86, 966-979. [CrossRef]

112. Rotko, D.; Kunz, W.S.; Szewczyk, A.; Kulawiak, B. Signaling pathways targeting mitochondrial potassium channels. Int. J. Biochem. Cell Biol. 2020, 125, 105792. [CrossRef] [PubMed]

113. O'Rourke, B. Evidence for mitochondrial $\mathrm{K}^{+}$channels and their role in cardioprotection. Circ. Res. 2004, 94, 420-432. [CrossRef]

114. Garlid, K.D.; Paucek, P.; Yarov-Yarovoy, V.; Murray, H.N.; Darbenzio, R.B.; D'Alonzo, A.J.; Lodge, N.J.; Smith, M.A.; Grover, G.J. Cardioprotective effect of diazoxide and its interaction with mitochondrial ATP-Sensitive $\mathrm{K}^{+}$channels. Possible mechanism of cardioprotection. Circ. Res. 1997, 81, 1072-1082. [CrossRef] [PubMed]

115. Grover, G.J.; Burkett, D.E.; Parham, C.S.; Scalese, R.J.; Sadanaga, K.K. Protective effect of mitochondrial KATP activation in an isolated gracilis model of ischemia and reperfusion in dogs. J. Cardiovasc. Pharmacol. 2003, 42, 790-792. [CrossRef] [PubMed]

116. Paggio, A.; Checchetto, V.; Campo, A.; Menabo, R.; Di Marco, G.; Di Lisa, F.; Szabo, I.; Rizzuto, R.; De Stefani, D. Identification of an ATP-Sensitive potassium channel in mitochondria. Nature 2019, 572, 609-613. [CrossRef]

117. Siemen, D.; Loupatatzis, C.; Borecky, J.; Gulbins, E.; Lang, F. Ca ${ }^{2+}$-Activated K channel of the BK-type in the inner mitochondrial membrane of a human glioma cell line. Biochem. Biophys. Res. Commun. 1999, 257, 549-554. [CrossRef]

118. Kohler, R. Single-Nucleotide polymorphisms in vascular $\mathrm{Ca}^{2+}$-activated $\mathrm{K}^{+}$-Channel genes and cardiovascular disease. Pflug. Arch. Eur. J. Physiol. 2010, 460, 343-351. [CrossRef]

119. Wang, X.; Yin, C.; Xi, L.; Kukreja, R.C. Opening of $\mathrm{Ca}^{2+}$-Activated $\mathrm{K}+$ channels triggers early and delayed preconditioning against I/R injury independent of NOS in mice. Am. J. Physiol. Heart Circ. Physiol. 2004, 287, H2070-H2077. [CrossRef]

120. Dai, H.; Wang, M.; Patel, P.N.; Kalogeris, T.; Liu, Y.; Durante, W.; Korthuis, R.J. Preconditioning with the BKCa channel activator NS-1619 prevents ischemia-reperfusion-induced inflammation and mucosal barrier dysfunction: Roles for ROS and heme oxygenase-1. Am. J. Physiol. Heart Circ. Physiol. 2017, 313, H988-H999. [CrossRef] 
121. Leanza, L.; Romio, M.; Becker, K.A.; Azzolini, M.; Trentin, L.; Manago, A.; Venturini, E.; Zaccagnino, A.; Mattarei, A.; Carraretto, L.; et al. Direct Pharmacological Targeting of a Mitochondrial Ion Channel Selectively Kills Tumor Cells In Vivo. Cancer Cell 2017, 31, 516-531. [CrossRef]

122. Zaccagnino, A.; Manago, A.; Leanza, L.; Gontarewitz, A.; Linder, B.; Azzolini, M.; Biasutto, L.; Zoratti, M.; Peruzzo, R.; Legler, K.; et al. Tumor-Reducing effect of the clinically used drug clofazimine in a SCID mouse model of pancreatic ductal adenocarcinoma. Oncotarget 2017, 8, 38276-38293. [CrossRef]

123. Chow, L.W.; Cheng, K.S.; Wong, K.L.; Leung, Y.M. Voltage-gated K(+) channels promote BT-474 breast cancer cell migration. Chin. J. Cancer Res. 2018, 30, 613-622. [CrossRef]

124. Szabo, I.; Zoratti, M. Mitochondrial channels: Ion fluxes and more. Physiol. Rev. 2014, 94, 519-608. [CrossRef] [PubMed]

125. Checchetto, V.; Azzolini, M.; Peruzzo, R.; Capitanio, P.; Leanza, L. Mitochondrial potassium channels in cell death. Biochem. Biophys. Res. Commun. 2018, 500, 51-58. [CrossRef] [PubMed]

126. Bachmann, M.; Rossa, A.; Antoniazzi, G.; Biasutto, L.; Carrer, A.; Campagnaro, M.; Leanza, L.; Gonczi, M.; Csernoch, L.; Paradisi, C.; et al. Synthesis and cellular effects of a mitochondria-targeted inhibitor of the Two-Pore potassium channel TASK-3. Pharmacol. Res. 2021, 164, 105326. [CrossRef] [PubMed]

127. Yang, K.C.; Bonini, M.G.; Dudley, S.C., Jr. Mitochondria and arrhythmias. Free. Radic. Biol. Med. 2014, 71, 351-361. [CrossRef]

128. Zotova, L.; Aleschko, M.; Sponder, G.; Baumgartner, R.; Reipert, S.; Prinz, M.; Schweyen, R.J.; Nowikovsky, K. Novel components of an active mitochondrial $\mathrm{K}(+) / \mathrm{H}(+)$ exchange. J. Biol. Chem. 2010, 285, 14399-14414. [CrossRef] [PubMed]

129. Hernansanz-Agustin, P.; Choya-Foces, C.; Carregal-Romero, S.; Ramos, E.; Oliva, T.; Villa-Pina, T.; Moreno, L.; Izquierdo-Alvarez, A.; Cabrera-Garcia, J.D.; Cortes, A.; et al. $\mathrm{Na}(+)$ controls hypoxic signalling by the mitochondrial respiratory chain. Nature 2020, 586, 287-291. [CrossRef]

130. Azarias, G.; Van de Ville, D.; Unser, M.; Chatton, J.Y. Spontaneous NA+ transients in individual mitochondria of intact astrocytes. Glia 2008, 56, 342-353. [CrossRef] [PubMed]

131. Kohlhaas, M.; Liu, T.; Knopp, A.; Zeller, T.; Ong, M.F.; Bohm, M.; O’Rourke, B.; Maack, C. Elevated cytosolic Na+ increases mitochondrial formation of reactive oxygen species in failing cardiac myocytes. Circulation 2010, 121, 1606-1613. [CrossRef] [PubMed]

132. Jung, D.W.; Apel, L.; Brierley, G.P. Matrix free $\mathrm{Mg}^{2+}$ changes with metabolic state in isolated heart mitochondria. Biochemistry 1990, 29, 4121-4128. [CrossRef] [PubMed]

133. Yamanaka, R.; Tabata, S.; Shindo, Y.; Hotta, K.; Suzuki, K.; Soga, T.; Oka, K. Mitochondrial Mg(2+) homeostasis decides cellular energy metabolism and vulnerability to stress. Sci. Rep. 2016, 6, 30027. [CrossRef] [PubMed]

134. Pradhan, R.K.; Qi, F.; Beard, D.A.; Dash, R.K. Characterization of $\mathrm{Mg}^{2+}$ inhibition of mitochondrial Ca ${ }^{2+}$ uptake by a mechanistic model of mitochondrial Ca2+ uniporter. Biophys. J. 2011, 101, 2071-2081. [CrossRef] [PubMed]

135. Gout, E.; Rebeille, F.; Douce, R.; Bligny, R. Interplay of $\mathrm{Mg}^{2+}, \mathrm{ADP}$, and ATP in the cytosol and mitochondria: Unravelling the role of Mg2+ in cell respiration. Proc. Natl. Acad. Sci. USA 2014, 111, E4560-E4567. [CrossRef]

136. Behrens, V.A.; Walter, W.J.; Peters, C.; Wang, T.; Brenner, B.; Geeves, M.A.; Scholz, T.; Steffen, W. Mg(2+)-Free ATP regulates the processivity of native cytoplasmic dynein. FEBS Lett. 2019, 593, 296-307. [CrossRef] [PubMed]

137. Niermann, K.J.; Olsen, N.J.; Park, J.H. Magnesium abnormalities of skeletal muscle in dermatomyositis and juvenile dermatomyositis. Arthritis Rheum. 2002, 46, 475-488. [CrossRef]

138. Iotti, S.; Malucelli, E. In vivo assessment of $\mathrm{Mg}^{2+}$ in human brain and skeletal muscle by 31P-MRS. Magnes. Res. 2008, 21, 157-162.

139. Pilchova, I.; Klacanova, K.; Tatarkova, Z.; Kaplan, P.; Racay, P. The Involvement of $\operatorname{Mg}(2+)$ in Regulation of Cellular and Mitochondrial Functions. Oxidative Med. Cell. Longev. 2017, 2017, 6797460. [CrossRef] [PubMed]

140. Matsui, Y.; Funato, Y.; Imamura, H.; Miki, H.; Mizukami, S.; Kikuchi, K. Visualization of Long- Term Mg(2+) dynamics in apoptotic cells using a novel targetable fluorescent probe. Chem. Sci. 2017, 8, 8255-8264. [CrossRef]

141. Cappadone, C.; Merolle, L.; Marraccini, C.; Farruggia, G.; Sargenti, A.; Locatelli, A.; Morigi, R.; Iotti, S. Intracellular magnesium content decreases during mitochondria-mediated apoptosis induced by a new indole-derivative in human colon cancer cells. Magnes. Res. 2012, 25, 104-111. [CrossRef]

142. Piskacek, M.; Zotova, L.; Zsurka, G.; Schweyen, R.J. Conditional knockdown of hMRS2 results in loss of mitochondrial Mg(2+) uptake and cell death. J. Cell. Mol. Med. 2009, 13, 693-700. [CrossRef] [PubMed]

143. Merolle, L.; Sponder, G.; Sargenti, A.; Mastrototaro, L.; Cappadone, C.; Farruggia, G.; Procopio, A.; Malucelli, E.; Parisse, P.; Gianoncelli, A.; et al. Overexpression of the mitochondrial Mg channel MRS2 increases total cellular Mg concentration and influences sensitivity to apoptosis. Met. Integr. Biometal Sci. 2018, 10, 917-928. [CrossRef] [PubMed]

144. Kuwamura, M.; Tanimura, S.; Hasegawa, Y.; Hoshiai, R.; Moriyama, Y.; Tanaka, M.; Takenaka, S.; Nagayoshi, H.; Izawa, T.; Yamate, J.; et al. Downregulation of aspartoacylase during the progression of myelin breakdown in the dmy mutant rat with mitochondrial magnesium channel MRS2 defect. Brain Res. 2019, 1718, 169-175. [CrossRef]

145. Sun, Q.; Zhong, W.; Zhang, W.; Zhou, Z. Defect of mitochondrial respiratory chain is a mechanism of ROS overproduction in a rat model of alcoholic liver disease: Role of zinc deficiency. Am. J. Physiol. Gastrointest. Liver Physiol. 2016, 310, G205-G214. [CrossRef]

146. Adebayo, O.L.; Adenuga, G.A.; Sandhir, R. Selenium and zinc protect brain mitochondrial antioxidants and electron transport chain enzymes following postnatal protein malnutrition. Life Sci. 2016, 152, 145-155. [CrossRef] [PubMed] 
147. Sensi, S.L.; Ton-That, D.; Sullivan, P.G.; Jonas, E.A.; Gee, K.R.; Kaczmarek, L.K.; Weiss, J.H. Modulation of mitochondrial function by endogenous $\mathrm{Zn}^{2+}$ pools. Proc. Natl. Acad. Sci. USA 2003, 100, 6157-6162. [CrossRef]

148. Medvedeva, Y.V.; Lin, B.; Shuttleworth, C.W.; Weiss, J.H. Intracellular Zn2+ accumulation contributes to synaptic failure, mitochondrial depolarization, and cell death in an acute slice oxygen-glucose deprivation model of ischemia. J. Neurosci. Off. J. Soc. Neurosci. 2009, 29, 1105-1114. [CrossRef]

149. Ji, S.G.; Weiss, J.H. Zn(2+)-induced disruption of neuronal mitochondrial function: Synergism with Ca(2+), critical dependence upon cytosolic $\mathrm{Zn}(2+)$ buffering, and contributions to neuronal injury. Exp. Neurol. 2018, 302, 181-195. [CrossRef]

150. Dineley, K.E.; Votyakova, T.V.; Reynolds, I.J. Zinc inhibition of cellular energy production: Implications for mitochondria and neurodegeneration. J. Neurochem. 2003, 85, 563-570. [CrossRef] [PubMed]

151. Pochwat, B.; Nowak, G.; Szewczyk, B. Relationship between Zinc (Zn (2+)) and Glutamate Receptors in the Processes Underlying Neurodegeneration. Neural Plast. 2015, 2015, 591563. [CrossRef]

152. Ji, S.G.; Medvedeva, Y.V.; Wang, H.L.; Yin, H.Z.; Weiss, J.H. Mitochondrial Zn(2+) Accumulation: A Potential Trigger of Hippocampal Ischemic Injury. Neurosci. Rev. J. Bringing Neurobiol. Neurol. Psychiatry 2019, 25, 126-138.

153. Ward, D.M.; Cloonan, S.M. Mitochondrial Iron in Human Health and Disease. Annu. Rev. Physiol. 2019, 81, 453-482. [CrossRef] [PubMed]

154. Lill, R.; Muhlenhoff, U. Iron-sulfur-protein biogenesis in eukaryotes. Trends Biochem. Sci. 2005, 30, 133-141. [CrossRef] [PubMed]

155. Rouault, T.A.; Tong, W.H. Iron-sulphur cluster biogenesis and mitochondrial iron homeostasis. Nat. Rev. Mol. Cell Biol. 2005, 6, 345-351. [CrossRef]

156. Taher, A.T.; Saliba, A.N. Iron overload in thalassemia: Different organs at different rates. Hematol. Am. Soc. Hematology. Educ. Program 2017, 2017, 265-271. [CrossRef] [PubMed]

157. Hara, Y.; Yanatori, I.; Tanaka, A.; Kishi, F.; Lemasters, J.J.; Nishina, S.; Sasaki, K.; Hino, K. Iron loss triggers mitophagy through induction of mitochondrial ferritin. EMBO Rep. 2020, 21, e50202. [CrossRef]

158. Muhlenhoff, U.; Stadler, J.A.; Richhardt, N.; Seubert, A.; Eickhorst, T.; Schweyen, R.J.; Lill, R.; Wiesenberger, G. A specific role of the yeast mitochondrial carriers MRS3/4p in mitochondrial iron acquisition under iron-limiting conditions. J. Biol. Chem. 2003, 278, 40612-40620. [CrossRef]

159. Zhang, Y.; Lyver, E.R.; Knight, S.A.; Lesuisse, E.; Dancis, A. Frataxin and mitochondrial carrier proteins, Mrs3p and Mrs4p, cooperate in providing iron for heme synthesis. J. Biol. Chem. 2005, 280, 19794-19807. [CrossRef]

160. Hamdi, A.; Roshan, T.; Sheftel, A.; Ponka, P. Interaction of Transferrin-Endosomes with Mitochondria: Implications for Iron Transport to Ferrochelatase in Erythroid Cells. Blood 2015, 126, 407. [CrossRef]

161. Gao, G.; Chang, Y.Z. Mitochondrial ferritin in the regulation of brain iron homeostasis and neurodegenerative diseases. Front. Pharmacol. 2014, 5, 19. [CrossRef]

162. Yang, H.; Yang, M.; Guan, H.; Liu, Z.; Zhao, S.; Takeuchi, S.; Yanagisawa, D.; Tooyama, I. Mitochondrial ferritin in neurodegenerative diseases. Neurosci. Res. 2013, 77, 1-7. [CrossRef]

163. Ito, H.; Kurokawa, H.; Matsui, H. Mitochondrial reactive oxygen species and heme, non-heme iron metabolism. Arch. Biochem. Biophys. 2021, 700, 108695. [CrossRef]

164. Karnati, S.; Luers, G.; Pfreimer, S.; Baumgart-Vogt, E. Mammalian SOD2 is exclusively located in mitochondria and not present in peroxisomes. Histochem. Cell Biol. 2013, 140, 105-117. [CrossRef]

165. Boycott, K.M.; Beaulieu, C.L.; Kernohan, K.D.; Gebril, O.H.; Mhanni, A.; Chudley, A.E.; Redl, D.; Qin, W.; Hampson, S.; Kury, S.; et al. Autosomal-Recessive Intellectual Disability with Cerebellar Atrophy Syndrome Caused by Mutation of the Manganese and Zinc Transporter Gene SLC39A8. Am. J. Hum. Genet. 2015, 97, 886-893. [CrossRef]

166. Park, J.H.; Hogrebe, M.; Gruneberg, M.; DuChesne, I.; von der Heiden, A.L.; Reunert, J.; Schlingmann, K.P.; Boycott, K.M.; Beaulieu, C.L.; Mhanni, A.A.; et al. SLC39A8 Deficiency: A Disorder of Manganese Transport and Glycosylation. Am. J. Hum. Genet. 2015, 97, 894-903. [CrossRef]

167. Tuschl, K.; Meyer, E.; Valdivia, L.E.; Zhao, N.; Dadswell, C.; Abdul-Sada, A.; Hung, C.Y.; Simpson, M.A.; Chong, W.K.; Jacques, T.S.; et al. Mutations in SLC39A14 disrupt manganese homeostasis and cause childhood-onset parkinsonism-dystonia. Nat. Commun. 2016, 7, 11601. [CrossRef] [PubMed]

168. Hutchens, S.; Liu, C.; Jursa, T.; Shawlot, W.; Chaffee, B.K.; Yin, W.; Gore, A.C.; Aschner, M.; Smith, D.R.; Mukhopadhyay, S. Deficiency in the manganese efflux transporter SLC30A10 induces severe hypothyroidism in mice. J. Biol. Chem. 2017, 292, 9760-9773. [CrossRef]

169. Mercadante, C.J.; Prajapati, M.; Conboy, H.L.; Dash, M.E.; Herrera, C.; Pettiglio, M.A.; Cintron-Rivera, L.; Salesky, M.A.; Rao, D.B.; Bartnikas, T.B. Manganese transporter Slc30a10 controls physiological manganese excretion and toxicity. J. Clin. Investig. 2019, 129, 5442-5461. [CrossRef] [PubMed]

170. Liu, Q.; Barker, S.; Knutson, M.D. Iron and manganese transport in mammalian systems. Biochim. Biophys. Acta. Mol. Cell Res. 2021, 1868, 118890. [CrossRef] [PubMed]

171. Kamer, K.J.; Sancak, Y.; Fomina, Y.; Meisel, J.D.; Chaudhuri, D.; Grabarek, Z.; Mootha, V.K. MICU1 imparts the mitochondrial uniporter with the ability to discriminate between $\mathrm{Ca}(2+)$ and $\mathrm{Mn}(2+)$. Proc. Natl. Acad. Sci. USA 2018, 115, E7960-E7969. [CrossRef]

172. Bowman, A.B.; Kwakye, G.F.; Herrero Hernandez, E.; Aschner, M. Role of manganese in neurodegenerative diseases. J. Trace Elem. Med. Biol. Organ Soc. Miner. Trace Elem. 2011, 25, 191-203. [CrossRef] 
173. Mezzaroba, L.; Alfieri, D.F.; Colado Simao, A.N.; Vissoci Reiche, E.M. The role of zinc, copper, manganese and iron in neurodegenerative diseases. Neurotoxicology 2019, 74, 230-241. [CrossRef]

174. Liu, Z.Q.; Liu, K.; Liu, Z.F.; Cong, L.; Lei, M.Y.; Ma, Z.; Li, J.; Deng, Y.; Liu, W.; Xu, B. Manganese-induced alpha-synuclein overexpression aggravates mitochondrial damage by repressing PINK1/Parkin-mediated mitophagy. Food Chem. Toxicol. Int. J. Publ. Br. Ind. Biol. Res. Assoc. 2021, 152, 112213. [CrossRef] [PubMed]

175. Chen, W.W.; Freinkman, E.; Sabatini, D.M. Rapid immunopurification of mitochondria for metabolite profiling and absolute quantification of matrix metabolites. Nat. Protoc. 2017, 12, 2215-2231. [CrossRef] [PubMed]

176. Chen, W.W.; Freinkman, E.; Wang, T.; Birsoy, K.; Sabatini, D.M. Absolute Quantification of Matrix Metabolites Reveals the Dynamics of Mitochondrial Metabolism. Cell 2016, 166, 1324-1337. [CrossRef]

177. Figueroa, J.A.; Stiner, C.A.; Radzyukevich, T.L.; Heiny, J.A. Metal ion transport quantified by ICP-MS in intact cells. Sci. Rep. 2016, 6, 20551. [CrossRef] [PubMed]

178. Nicolli, A.; Trevisan, A.; Bortoletti, I.; Pozzuoli, A.; Ruggieri, P.; Martinelli, A.; Gambalunga, A.; Carrieri, M. Biological Monitoring of Metal Ions Released from Hip Prostheses. Int. J. Environ. Res. Public Health 2020, 17, 3223. [CrossRef] [PubMed]

179. Toninello, A.; Clari, G.; Mancon, M.; Tognon, G.; Zatta, P. Aluminum as an inducer of the mitochondrial permeability transition. J. Biol. Inorg. Chem. JBIC A Publ. Soc. Biol. Inorg. Chem. 2000, 5, 612-623. [CrossRef]

180. Khezri, S.; Sabzalipour, T.; Jahedsani, A.; Azizian, S.; Atashbar, S.; Salimi, A. Chrysin ameliorates aluminum phosphide-induced oxidative stress and mitochondrial damages in rat cardiomyocytes and isolated mitochondria. Environ. Toxicol. 2020, 35, 1114-1124. [CrossRef]

181. Zischka, H.; Einer, C. Mitochondrial copper homeostasis and its derailment in Wilson disease. Int. J. Biochem. Cell Biol. 2018, 102, 71-75. [CrossRef] [PubMed]

182. Singh, R.P.; Jeyaraju, D.V.; Voisin, V.; Hurren, R.; Xu, C.; Hawley, J.R.; Barghout, S.H.; Khan, D.H.; Gronda, M.; Wang, X.; et al. Disrupting Mitochondrial Copper Distribution Inhibits Leukemic Stem Cell Self-Renewal. Cell Stem Cell 2020, 26, 926-937. [CrossRef] [PubMed]

183. Cui, L.; Gouw, A.M.; LaGory, E.L.; Guo, S.; Attarwala, N.; Tang, Y.; Qi, J.; Chen, Y.S.; Gao, Z.; Casey, K.M.; et al. Mitochondrial copper depletion suppresses Triple-Negative breast cancer in mice. Nat. Biotechnol. 2021, 39, 357-367. [CrossRef] [PubMed] 